\title{
Accumulation and concentration of nitrogen, phosphorus and potassium in Jerusalem artichoke in a semi-arid region
}

\author{
Tongcheng Fu, ${ }^{1,2}$ Zuxin Liu, ${ }^{1-3}$ Yang Yang, ${ }^{1,2}$ Guang Hui Xie ${ }^{1,2}$ \\ ${ }^{1}$ College of Agronomy and Biotechnology, China Agricultural University, Beijing; ${ }^{2}$ National Energy R\&D \\ Center for Biomass, China Agricultural University, Beijing; ${ }^{3}$ Chinese Academy of Agricultural Engineering, \\ Beijing, P.R. China
}

\begin{abstract}
Jerusalem artichoke (Helianthus tuberosus L.) has been recognized as being a biomass crop for energy and livestock forage production. In this study, 26 Jerusalem artichoke clones previously collected from 24 provinces of China were grown under semiarid conditions in 2008 and 2011. At harvest, nitrogen (N), phosphorus $(\mathrm{P})$ and potassium $(\mathrm{K})$ concentrations and accumulations were measured for all clones and levels of both were higher overall for 2008 than 2011, with statistically reasonable results for both years. Notably, $\mathrm{N}$ and $\mathrm{K}$ concentrations in aboveground parts were higher than in tubers for most clones, yet the tuber P concentration was consistently higher than in aboveground parts. Comparing with other forage and energy plants, it demonstrates that under optimal conditions, diverse Jerusalem artichoke clones could meet the requirements of either energy production or livestock forage feed. Based on N, P and $\mathrm{K}$ accumulation and concentration profiles, the 26 Jerusalem artichoke clones clustered into six groups. Three clones of one cluster, CQ-1, GZ-1 and HUN-3, are recommended for use as biomass energy materials due to the lower $\mathrm{N}$ concentration level in aboveground parts and higher $\mathrm{N}$ concentration level in tubers, while 16 clones are recommended for use as forage due
\end{abstract}

Correspondence: Guang Hui Xie, College of Agronomy and Biotechnology; and National Energy R\&D Center for Biomass, China Agricultural University, Beijing 100193, P.R. China.

E-mail: xiegh@cau.edu.cn

Key words: Nutrient uptake; bio-fuel; biomass crop; forage crop.

Acknowledgements: this research was supported by the Department of Energy Conservation and Technology Equipment of China's National Energy Administration (Science and Technology Department, No. [2012] 32) and funded by China Datang New Energy Co. LTD and Henan Tianguan Group Co., Ltd.

Received for publication: 23 December 2016.

Revision received: 6 October 2017.

Accepted for publication: 9 October 2017.

(C) Copyright T. Fu et al., 2018

Licensee PAGEPress, Italy

Italian Journal of Agronomy 2018; 13:906

doi:10.4081/ija.2018.906

This article is distributed under the terms of the Creative Commons Attribution Noncommercial License (by-nc 4.0) which permits any noncommercial use, distribution, and reproduction in any medium, provided the original author(s) and source are credited. to the higher $\mathrm{N}$ concentration level in aboveground parts. The phenotypic traits described in this work should facilitate quantitative trait locus mapping and the subsequent use of clone germplasms for development of improved varieties suited to specific growth conditions and applications.

\section{Introduction}

The Jerusalem artichoke (Helianthus tuberosus L.) has garnered much attention for its high potential value as a feedstock source for biomass energy production and livestock forage. High levels of inulin and fructose account for $75 \%$ of its total dry tuber weight (Baldini et al., 2004; Kays and Nottingham, 2008); thus, this crop may serve as a promising raw material for the industrial production of biodiesel (Cheng et al., 2009), ethanol (Baldini et al., 2004), methane (Lehtomaki, 2005) and biomass briquettes or pellets (Kowalczyk-Jusko et al., 2012). Importantly, use of phenotypically diverse crops may allow biomass content control, as previous studies of energy biomass materials have suggested that such control should help to avoid negative environmental influences. For example, during combustion of briquettes or pellets (Jenkins et al., 1998), excess nitrogen (N) in raw materials would directly lead to higher emission of nitrides and hydrogen cyanide during combustion. Hence, development of Jerusalem artichoke varieties with lower N content would enhance this crop's value as a raw material in the biomass briquette industry. However, for other applications, higher nitrogen levels might be a desirable trait because the residues from anaerobic digestion of plant biomass for energy production contain mineralised nitrogen, a readily available $\mathrm{N}$ source for growing plants. Thus, higher $\mathrm{N}$ levels contribute to higher by-product quality after anaerobic digestion. Because Jerusalem artichoke tubers contain high $\mathrm{N}$ levels, tubers would thus be better suited for use in ethanol production than for production of biomass briquettes. The N-rich residues produced by anaerobic digestion could thus be returned to the cultivation soil to serve as a fertiliser and soil-improvement medium (Demuynck, 1984; Hons et al., 1993; Karpenstain-Machan, 2001).

Comparing with corn silage, tuber of Jeruslaem artichoke showed to have a higher digestible protein content (Kays and Nottingham, 2008). While tubers show potential value, aboveground parts of the Jerusalem artichoke have already long been used as an ideal raw livestock forage for ruminants in cool, wet areas of Europe (Kosaric et al., 1984; Hay and Offer, 1992; Youngen, 1992; Cosgrove et al., 2000) and in North America (Crawford et al., 1969; Seiler, 1993). For this reason, previous studies have focused on evaluation of in vitro digestible dry matter from aboveground parts of the plant (Tilley and Terry, 1963; Seilier, 1993). Other studies of perennial silage/forage crops have 
additionally demonstrated that mineral element composition and quantity should also be assessed (Buxton, 1996) because multiple inorganic elements, including calcium, phosphorus $(\mathrm{P})$, sodium, chlorine, potassium $(\mathrm{K})$, magnesium and sulfur, are essential for normal livestock growth and reproduction (National Academy of Sciences, 2001).

Aside from the applications outlined above, the Jerusalem artichoke holds promise for use in desertification control (Ma et al., 2011), due to its high tolerance of drought and saline-alkali conditions (Zhao et al., 2010a). However, the utilisation of the plant's underground tubers could cause environmental problems, as the harvest of tubers would cause soil erosion. Therefore, harvest of only aboveground parts is recommended in some environmentally stressed areas. For such applications, the assessment of the quantity and concentration of macroelements in the aboveground parts of the Jerusalem artichoke would be a valuable indicator to inform germplasm selection of pasture varieties for use in ecologically sensitive regions.

Regardless of application, the uptake and utilisation of mineral nutrients, which are closely related to plant growth and yield, are mainly dependent on environmental water (Pilnik and Vervelde, 1976; Mezencev, 1985; Conde et al., 1988; Ben Chekroun et al., 1996) and soil conditions (Kosaric et al., 1984). Although Jerusalem artichokes could be grown in poor soils without high fertiliser input, the resulting tuber sizes tend to be smaller and are accompanied by low aboveground biomass yields (Huxley, 1992). Therefore, an appropriate fertilisation management strategy is needed for optimising biomass accumulation of both Jerusalem artichoke tubers and aboveground aerial parts depending on their intended applications. In our previous study, we evaluated phenological development, morphological traits, shoot biomass and tuber yields of 26 Jerusalem artichoke clones grown in the semiarid region of the Loess Plateau of China (Liu et al., 2012). The objectives of this study were (i) to investigate changes in concentrations and uptake of N, P and K over a growth period of 180 days for 26 Jerusalem artichoke clones and (ii) to group the clones into different clusters according to the nutrient properties.

\section{Materials and methods}

\section{Study site}

All field experiments were carried out in 2008 and 2011 in a semiarid region of the Loess Plateau Experimental Station of Lanzhou University $\left(35^{\circ} 37^{\prime} \mathrm{N}, 107^{\circ} 48^{\prime} \mathrm{E}, 1298 \mathrm{~m}\right.$ above sea level). The multi-year mean annual solar radiation duration, temperature and precipitation from July to September were $2490 \mathrm{~h}, 556.1 \mathrm{~mm}$ and $9.6^{\circ} \mathrm{C}$, respectively. The soil at the site was Heilu with a clay texture, $\mathrm{pH} 7.7$, and organic matter of $13.10 \mathrm{~g} \mathrm{~kg}^{-1}$ in the $0-20 \mathrm{~cm}$ layer. Total rainfall were $335 \mathrm{~mm}$ and $297 \mathrm{~mm}$ during the growth periods in 2008 and 2011, respectively, with $78.3 \%$ and $83.8 \%$ falling between July and September. Soil water potential at the 0$20 \mathrm{~cm}$ layer fluctuated from -25 to $-80 \mathrm{kPa}$ during the $180 \mathrm{~d}$ of the Jerusalem artichoke clone growth. More detailed seasonal weather data, soil texture and moisture data at the study site in 2008 and 2011 have been described in our previous report (Liu et al., 2012).

\section{Experimental design}

A total of 26 Jerusalem artichoke clones were assessed in this study. The experimental design was a completely randomized block with triplicate plots in 2008 and in quadruplicate plots in
2011. Each plot was $1.6 \times 2.8 \mathrm{~m}$ in size and allocated into 4 rows with a row spacing of $0.7 \mathrm{~m}$ and hill spacing of $0.4 \mathrm{~m} .50 \mathrm{~g}$ of tubers for propagation collected from different clones were individually planted in each plot on April $1^{\text {st }}$ after the field was well ploughed and harrowed in the early spring. Guard rows were also set up to surround areas containing each single clone to prevent potential crop identification errors. Basal fertiliser consisted of 150 $\mathrm{N} \mathrm{kg} \mathrm{ha}{ }^{-1}$ as urea, $75 \mathrm{~kg} \mathrm{P}_{2} \mathrm{O}_{5} \mathrm{ha}^{-1}$ as superphosphate and $120 \mathrm{~kg}$ $\mathrm{K}_{2} \mathrm{O}$ ha $^{-1}$ as potassium sulphate, which were applied one day before planting. Surface irrigation was applied with an amount of $50 \mathrm{~m}^{3} \mathrm{ha}^{-1}$ water for each plot on March $31^{\text {st }}$. Weed was removed manually in all plots at the seedling stage. No additional irrigation and weed control was applied prior to the harvest dates on October $1^{\text {st }}$ of each year.

\section{Sampling and measurements}

The aboveground biomass in each plot was collected on each harvest date by cutting the plants at ground level and weighing the fresh aboveground biomass. From the leaf, and stem parts were separated, cut into pieces of $2-3 \mathrm{~cm}$ in length, then oven-dried to constant weight at $105^{\circ} \mathrm{C}$ to determine moisture content. Dry biomass weights of aboveground stem and leaf in each plot were calculated by multiplying fresh biomass weight by its dry matter content $(100 \%$-moisture content). Fresh tubers in each plot were harvested manually and further washed, counted and weighed to determine tuber size, fresh weight and numbers of tubers per plant. A subset of tubers was cut into $1.5 \mathrm{~cm}$-thick slices and oven-dried to constant weight at $105^{\circ} \mathrm{C}$. Thereafter, dried tuber slices were crushed and passed through a $0.5 \mathrm{~mm}$ mesh screen for subsequent chemical analyses. The total dry biomass yield of Jerusalem artichokes was calculated by adding the aboveground biomass yield from leaf and stem parts to the tuber biomass yield.

\section{Chemical analysis}

Samples of tubers and aboveground parts (leaf and stem) were first digested with $\mathrm{H}_{2} \mathrm{SO}_{4}-\mathrm{H}_{2} \mathrm{O}_{2}$ following a Kjeldahl digestion protocol (Wolf, 1982). N, P and K concentrations were determined using the semimicro-Kjeldahl digestion and distillation method (Nelson and Sommers, 1980), vanadomolybdate yellow method (Jackson, 1958) and flame spectroanalysis, respectively. The determinations of $\mathrm{N}, \mathrm{P}$ and $\mathrm{K}$ concentrations for each plot were derived from the averaged values of 3 replicate plots in 2008 and 4 replicate plots in 2011 .

\section{Calculation and statistical analysis}

The nutrient accumulations in aboveground parts and tubers were computed as the product of the concentration multiplied by the dry biomass weight for each replicate. Means and standard errors were calculated from replicate data for each treatment.

The nutrient data of the 26 Jerusalem artichoke clones were analysed by determining the maximum and minimum values and calculating the standard error. A correlation between concentration and accumulation for each of the three elements was conducted. Two-way ANOVA was conducted for the purpose of examining the effects of year and clone factors on nutrient concentrations using SPSS software package. The significance of the differences between means was determined using the least significant difference at the $\mathrm{P}<0.05$ level. The two-year mean concentration and accumulation values for each clone were used for hierarchical cluster analysis using Ward's method. Cluster and principal components analysis were performed using the SPSS Statistics 20 software package (SPSS, IBM Corp., 2011). 


\section{Results}

\section{Cluster analysis}

The 26 Jerusalem artichoke clones were sorted into 6 clusters on the basis of N, P and K accumulation and concentration in 2008 and 2012 (Figure 1). Mean values and standard errors of accumulation and concentration for each cluster are presented in Figure 2. Cluster $\mathrm{K}_{1}$ with 3 clones was characterised by relatively high levels concentration and accumulation of $\mathrm{N}$ and $\mathrm{K}$ in aboveground parts, low levels of $\mathrm{N}$ concentration and accumulation in tubers. Cluster $\mathrm{K}_{2}$ including 6 clones exhibited relatively high concentration and accumulation levels of $\mathrm{P}$ and $\mathrm{K}$ in tubers and low accumulation of $\mathrm{P}$ and $\mathrm{K}$ in aboveground parts. Cluster $\mathrm{K}_{3}$ including 2 clone shown the lowest $\mathrm{P}$ and $\mathrm{K}$ concentration levels in tubers, and highest $\mathrm{N}$, and $\mathrm{K}$ concentration levels in aboveground part. Cluster $\mathrm{K}_{4}$ with 3 clones characterised the highest concentration and accumulation levels of $\mathrm{N}$ and $\mathrm{P}$ in tubers. Cluster $\mathrm{K}_{5}$ including 2 clones exhibited relatively low concentration and accumulation levels of both $\mathrm{N}, \mathrm{P}$, and $\mathrm{K}$ in tubers. Cluster $\mathrm{K}_{6}$ was the largest group with 10 clones and characterised by relatively low $\mathrm{N}$ concentration level in tubers and high $\mathrm{N}$ accumulation in aboveground parts.

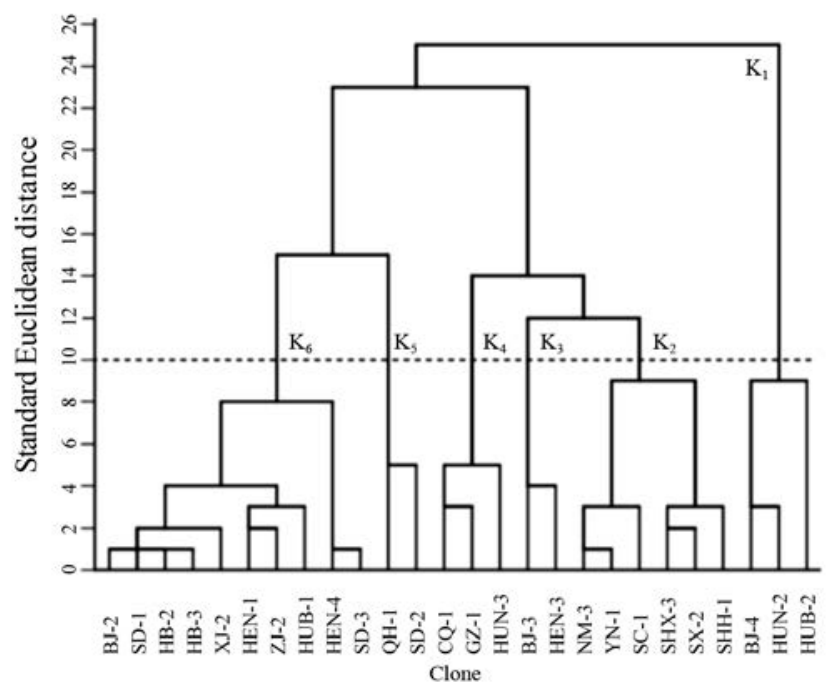

Figure 1. Dendrogram obtained by cluster analysis of concentrations and biomass accumulation of nitrogen $(\mathrm{N})$, phosphorus $(\mathrm{P})$ and potassium $(\mathrm{K})$ in 26 Jerusalem artichoke clones following Ward's method.
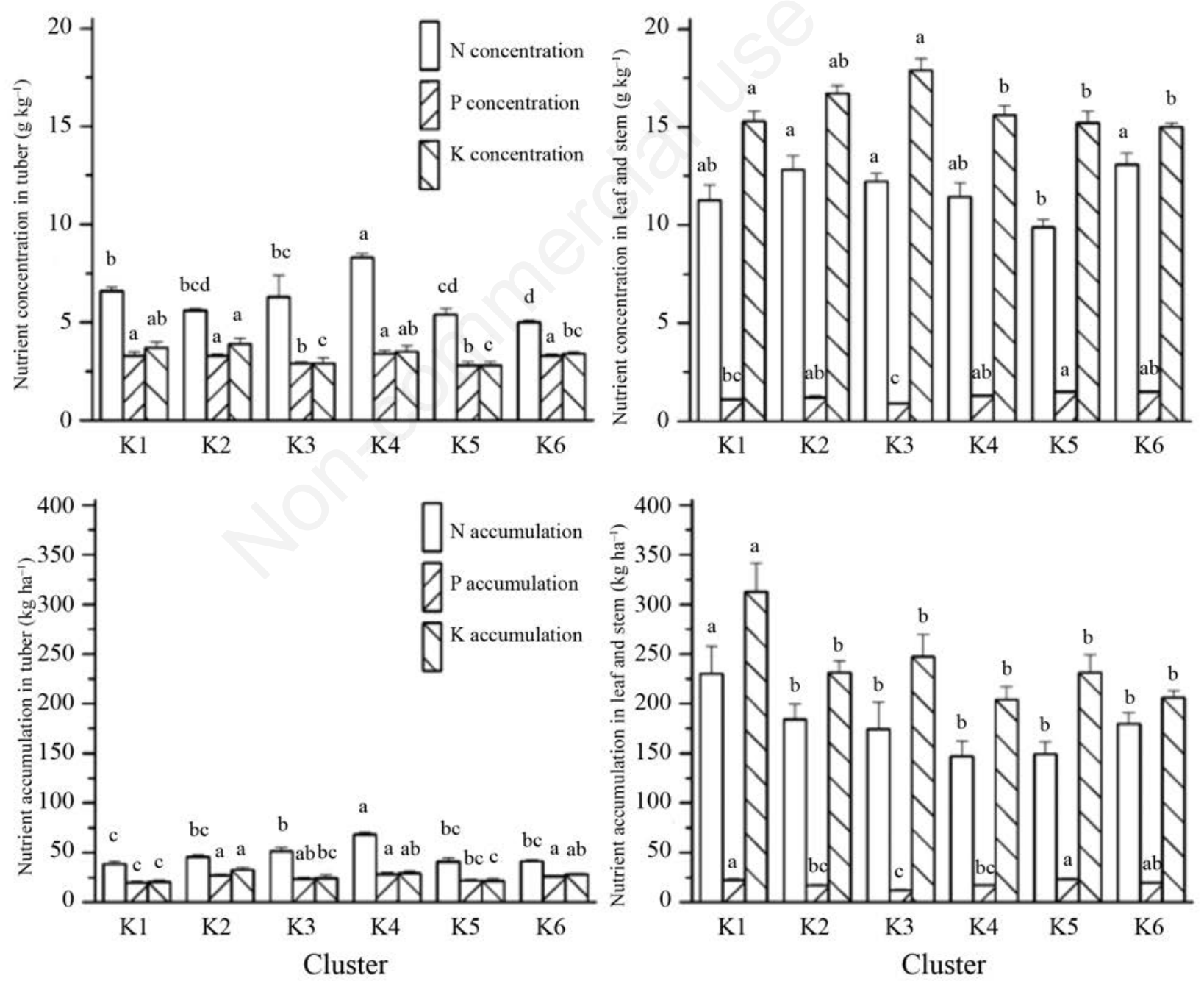

Figure 2. Averaged concentrations and accumulations of nitrogen $(\mathrm{N})$, phosphorus $(\mathrm{P})$ and potassium $(\mathrm{K})$ in tubers, and aboveground parts at harvest date for the six clusters of Jerusalem artichoke grown in 2008 and 2011 . Vertical error bars represent standard deviations. Different lower letters within the same parameter represent statistical significance between clusters at $P<0.05$ level. 
Article

$\mathbf{N}, P$ and $K$ concentrations in aboveground parts

Relative to tubers, sample from all Jerusalem artichoke clone aboveground parts exhibited lower $\mathrm{K}$ concentration levels than either $\mathrm{N}$ or P concentration levels for both years (Figure 3). The 26 Jerusalem artichoke clones exhibited $\mathrm{N}$ concentrations ranging between 9.33-22.66 $\mathrm{g} \mathrm{N} \mathrm{kg}^{-1}$, P concentrations between 0.81-1.65 g P kg -1 and $\mathrm{K}$ concentrations between $14.53-20.38 \mathrm{~g} \mathrm{~K} \mathrm{~kg}^{-1}$ for both years. The average $\mathrm{N}$ and $\mathrm{K}$ concentrations in the aboveground parts of all 26 clones were both lower, by $78.9 \%$ and $19.1 \%$, respectively, in 2011 than in 2008, whereas the average P concentration did not vary significantly $(\mathrm{P}<0.05)$. Two-way ANOVA demonstrating the effects of factors of planting year,
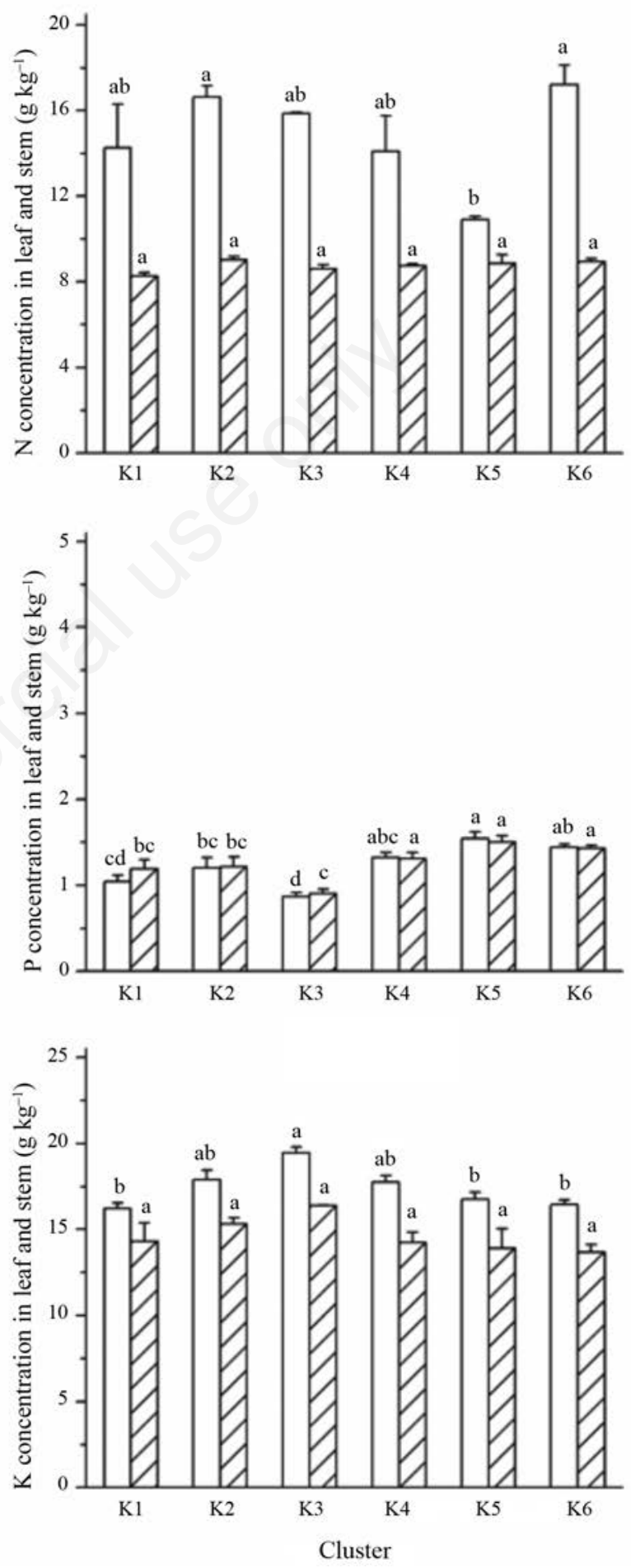

Figure 3. Concentrations of nitrogen $(N)$, phosphorus $(P)$ and potassium $(K)$ in tubers and aboveground parts at harvest date for six clusters of Jerusalem artichoke grown in 2008 and 2011. Vertical error bars represent standard deviations. Different lower letters within the same parameter represent statistical significance between clusters at $\mathrm{P}<0.05$ level.

[page 188]

[Italian Journal of Agronomy 2018; 13:906]

OPEN

ACCESS 
clone and their interaction factor on the concentrations of the three elements in aboveground parts demonstrated that most variances in the independent and interaction factors were significant at the $\mathrm{P}<0.001$ level, however the variance for year $\times$ clone effects on $\mathrm{N}$ concentration was not significant.

\section{$N, P$ and $K$ concentrations in tubers}

Cluster average concentrations of N, P and K in tubers in 2008 and 2011 are shown in Figure 3. Generally, the 26 clones tended to have a higher $\mathrm{N}$ concentration in aboveground parts than in tubers in both years. In contrast, $\mathrm{P}$ and $\mathrm{K}$ concentrations were higher in tubers than in aboveground parts. Average $\mathrm{N}$ concentrations of the six clusters were $6.85 \mathrm{~g} \mathrm{~N} \mathrm{~kg}^{-1}$ and $5.72 \mathrm{~g} \mathrm{~N} \mathrm{~kg}^{-1}$, average $\mathrm{P}$ concentrations were $2.53 \mathrm{~g} \mathrm{P} \mathrm{kg}^{-1}$ and $3.65 \mathrm{~g} \mathrm{P} \mathrm{kg}^{-1}$, and average $\mathrm{K}$ concentrations were $4.59 \mathrm{~g} \mathrm{~K} \mathrm{~kg}^{-1}$ and $2.45 \mathrm{~g} \mathrm{~K} \mathrm{~kg}^{-1}$ in 2008 and 2012, respectively. Average N, P and $\mathrm{K}$ concentration in the tubers of the clones planted in 2008 were higher by $21.2 \%$ and $89.5 \%$, respectively; whereas average P concentration in tubers in 2008 was lower by $31.1 \%$ in comparison with those in 2011. Two-way ANOVA demonstrating effects of factors of year and clone and their interaction factor on tuber N, P and K concentrations generated results that were similar to aboveground part results. However, in tubers the independent and interaction factors were all significantly affected by $\mathrm{N}, \mathrm{P}$ and $\mathrm{K}$ concentrations at the $\mathrm{P}<0.01$ level.

\section{$\mathbf{N}, \mathbf{P}$ and $\mathrm{K}$ accumulations}

The $\mathrm{N}$ accumulation in aboveground parts was higher than in tubers, due to the higher $\mathrm{N}$ concentration and biomass in aboveground parts (Figure 2). Moreover, even though the concentrations of $\mathrm{P}$ and $\mathrm{K}$ in tubers were both generally higher than in aboveground parts, the accumulation of $\mathrm{P}$ and $\mathrm{K}$ in aboveground parts of most clones were still higher than for tubers overall, due to the overwhelming higher biomass present in aboveground parts.

$\mathrm{N}$ accumulation exhibited a significantly much higher level in the aboveground parts $\left(129.98-416.87 \mathrm{~kg} \mathrm{~N} \mathrm{ha}^{-1}\right)$ than that in tubers $\left(27.78-81.67 \mathrm{~kg} \mathrm{~N} \mathrm{ha}^{-1}\right)$ across the six clusters $(\mathrm{P}<0.01)$ in both years (Figure 2). K accumulation, ranging between 20.48$55.41 \mathrm{~kg} \mathrm{~K} \mathrm{ha}^{-1}$ in tubers and $181.84-522.62 \mathrm{~kg} \mathrm{~K} \mathrm{ha}^{-1}$ in aboveground part, followed the same pattern as $\mathrm{N}$ accumulation. However, the difference in $\mathrm{P}$ accumulation between aboveground parts (12.63-31.29 $\left.\mathrm{kg} \mathrm{P} \mathrm{ha}^{-1}\right)$ and tubers (9.17-27.18 $\mathrm{kg} \mathrm{P} \mathrm{ha}^{-1}$ ) was not significant for each of all the clusters with the exception of cluster $\mathrm{K}_{6}(\mathrm{P}<0.05)$. The variance of the nutrient accumulations between the two years was the same as for nutrient concentrations. The accumulations of the three elements were generally lower in 2011 than in 2008, except for P accumulation in tubers. The mean values of tuber $\mathrm{N}, \mathrm{P}$ and $\mathrm{K}$ accumulations were lower by $22.2 \%$, $-34.6 \%$ and $50 \%$, respectively. The average N, P and K accumulations in aboveground parts were lower by $60.4 \%, 28.0 \%$ and $41.1 \%$, respectively (Figure 4). Two-way ANOVA showed that the $\mathrm{N}, \mathrm{P}$ and $\mathrm{K}$ accumulations in both aboveground and tuber parts were all significantly affected by the year, clone and the interaction of year $\times$ clone factors at the $\mathrm{P}<0.001$ level.

\section{Statistical analysis}

Correlations between N, P and $\mathrm{K}$ accumulations and concentrations were calculated using the mean values for the 26 clones for both years (Table 1). In agreement with previously established plant nutrition concepts, a significant and positive correlation between $\mathrm{N}, \mathrm{P}$ and $\mathrm{K}$ accumulations and their corresponding concentrations in both aboveground parts and tubers was demonstrated $(\mathrm{P}<0.01)$.

\section{Discussion}

\section{Correlation of $\mathbf{N}, \mathbf{P}$ and $\mathrm{K}$ concentrations with biomass yield}

According to a previous report (Liu et al., 2011) based on the same field experiment of this study, the 26 Jerusalem artichoke clones exhibited biomass yield ranging from 9.7 ton $\mathrm{ha}^{-1}$ to 31.3 ton $\mathrm{ha}^{-1}$ for aboveground parts and from 3.7 ton $\mathrm{ha}^{-1}$ to 10.6 ton $\mathrm{ha}^{-1}$ for tubers in both year 2008 and 2011. The total biomass of above ground parts and tubers ranged from 16.1 ton ha $\mathrm{ha}^{-1}$ to 35.0 ton $\mathrm{ha}^{-1}$. The yield data and our finding were used to analyze the correlation of $\mathrm{N}, \mathrm{P}$ and $\mathrm{K}$ concentrations with biomass yield and found that none of the three nutrient concentrations was significantly correlated with biomass yield of aboveground parts and tubers $(\mathrm{P}<0.05)$.

\section{$\mathrm{N}, \mathrm{P}$ and $\mathrm{K}$ concentrations in tubers and aboveground parts}

All clones in this study exhibited tuber $\mathrm{N}$ concentrations ranging between 3.98-9.50 $\mathrm{g} \mathrm{N} \mathrm{kg}^{-1}$ averaged over both years. This level was about a half of the $\mathrm{N}$ concentration values (7.0-21.8 $\mathrm{g} \mathrm{N} \mathrm{kg}^{-1}$ ) in tubers reported by Kays and Nottingham (2008), who did a field experiment with 140 Jerusalem artichoke clones. The main reasons accounting for lower $\mathrm{N}, \mathrm{P}$ and $\mathrm{K}$ concentrations observed in this work were likely due to the lower $\mathrm{N}$ fertilisation rate and earlier harvest date used here. Although the required $\mathrm{N}$ fertiliser rate for this crop was reported to range from $60-120 \mathrm{~kg} \mathrm{~N}^{-1}$ (Barloy, 1988; Fernandez et al., 1988; Honermeier et al., 1996), the practical $\mathrm{N}$ requirement varied between clones. The sufficient $\mathrm{N}$ fertiliser for numerous clones has been reported to range from $150-225 \mathrm{~N} \mathrm{~kg} \mathrm{ha}^{-}$ 1 by many researchers studying Jerusalem artichoke agronomy practices in China (Niu, 2005; Zhao et al., 2010b; Zhu et al., 2014). Therefore, the fertilisation rate of $150 \mathrm{~kg} \mathrm{~N} \mathrm{ha}^{-1}$ applied in our study was a relatively medium or low-level application rate. Considering the proper cropping season for Jerusalem artichoke in China is from March-May to middle October (Niu, 2005), our slightly earlier harvest date might cause our results for the $\mathrm{N}$ partition from leaf to tuber to differ from that observed by other researchers who used longer growth season duration. In our study, the $\mathrm{N}$ concentration of harvested aboveground parts over both years ranged from 7.87-22.66 $\mathrm{kg} \mathrm{N} \mathrm{ha}^{-1}$, almost two times higher than the tuber $\mathrm{N}$ concentration range of $3.98-9.50 \mathrm{~kg} \mathrm{~N} \mathrm{ha}^{-1}$.

\section{$\mathrm{N}, \mathrm{P}$ and $\mathrm{K}$ uptake and responses to environmental influences}

The Jerusalem artichoke has long been reported to be an extremely efficient crop for nutrient uptake of its tubers and above-

Table 1. Coefficients of correlation between concentration and accumulation of nitrogen (N), phosphorus (P), and potassium $(\mathrm{K})$ in tubers and aboveground parts of 26 Jerusalem artichoke clones.

\begin{tabular}{lrc} 
Nutrient & Tuber & Coefficient \\
& & Aboveground part \\
$\mathrm{N}$ & $0.773^{* *}$ & $0.878^{* *}$ \\
$\mathrm{P}$ & $0.622^{* *}$ & $0.457^{* *}$ \\
\hline $\mathrm{K}$ & $0.831^{* *}$ & $0.587^{* *}$ \\
\hline$* *$ Significant effect at $\mathrm{P}<0.01$ level. &
\end{tabular}


Article

ground parts (Rays and Nottingham, 2008). The clones cultivated in this experiment showed a relatively higher $\mathrm{N}$ and $\mathrm{K}$ uptake levels than sweet sorghum, miscanthus, and witchgrass, which were reported by Han et al. (2011), Beale and Long (1997) and Wilson et al. (2013), respectively. However Jerusalem artichoke exhibited a lower P uptake level than sweet sorghum (Han et al. 2011). The most possible reason for this could be $\mathrm{N}$ and $\mathrm{K}$ concentrations in Jerusalem artichoke in this study were higher than those plants in the previous reports, and $\mathrm{P}$ concentration with the reverse.

A plant is as well responsive to supplemental fertiliser applicaton (Sim and Lee, 1983). Therefore, proper fertilisation managemont is recommended to ensure sustainable cultivation. Notably,
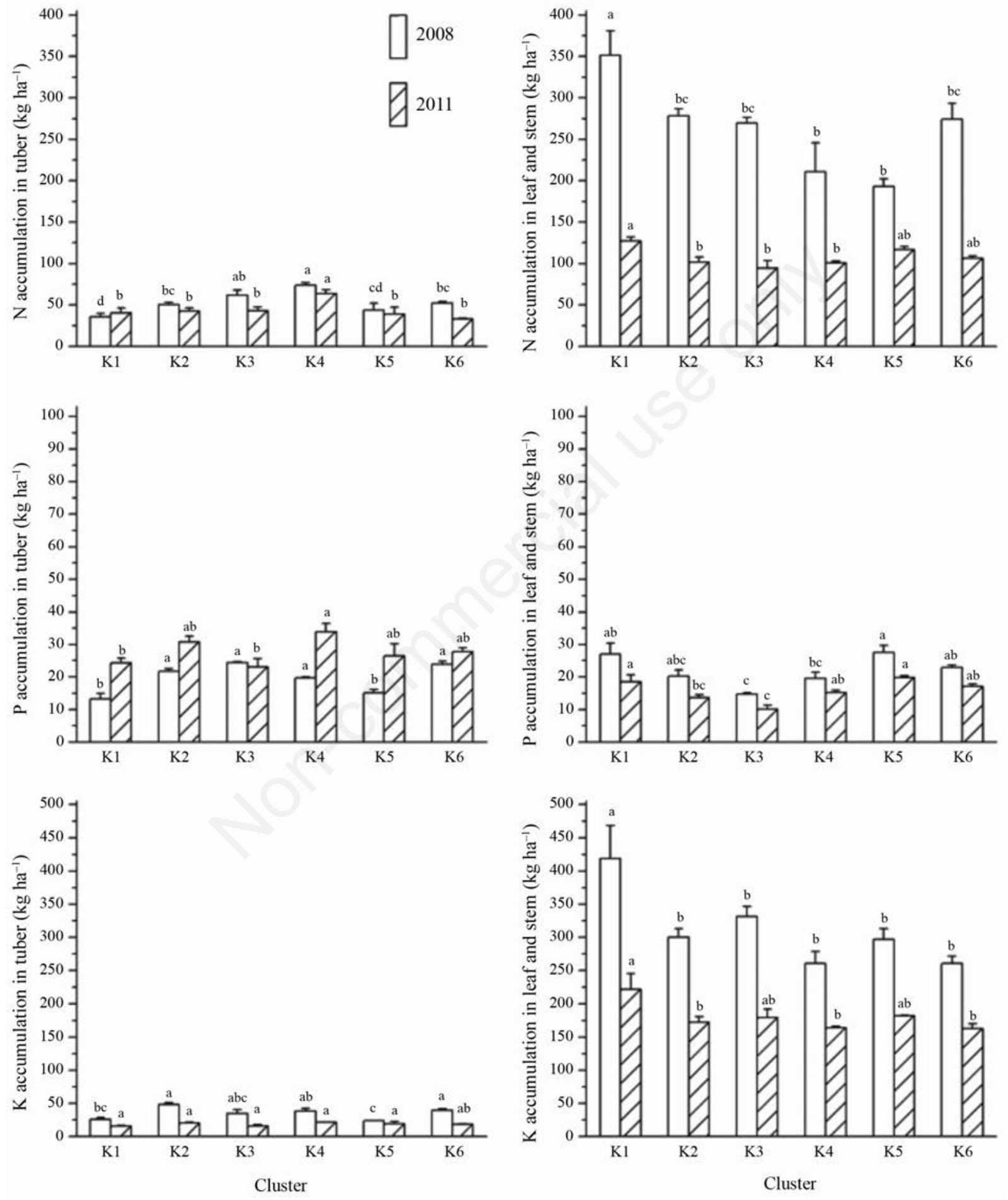

Figure 4. Accumulations of nitrogen $(\mathrm{N})$, phosphorus $(\mathrm{P})$ and potassium $(\mathrm{K})$ in tubers and aboveground parts at harvest date for six clusters of Jerusalem artichoke grown in 2008 and 2011. Vertical error bars represent standard deviations. Different lower letters within the same parameter represent statistical significance between clusters at $\mathrm{P}<0.05$ level.

[page 190]

[Italian Journal of Agronomy 2018; 13:906]

OPEN

ACCESS 
on the basis of our experiments, the amount of $\mathrm{N}, \mathrm{P}$ and $\mathrm{K}$ removed from the field were larger than the fertiliser amount applied at the beginning of the experiments. As a consequence of insufficient fertilisation, the tuber yield and N, P and K accumulations in 2011 were generally lower than, or consistent with, those in 2008. Thus, higher fertilisation application rates should be used to ensure continuous Jerusalem artichoke cultivation.

Although the Jerusalem artichoke has been considered to be drought tolerant, the level of phloem-mobile elements (e.g. nitrogen, phosphorus, potassium), which would be allocated to the tuber, would also be affected by drought stress late in the season (Nemeth and Izsaki, 2006). Although few studies on the Jerusalem artichoke have reported results of nutrient status analysis, Seiler and Campbell (2006) compared the within-population variation for several minerals. The within-population variations were high for $\mathrm{N}, \mathrm{Ca}$ and $\mathrm{K}$ and low for $\mathrm{P}$ and $\mathrm{Mg}$. Monti et al. (2005) reported leaf $\mathrm{N}$ concentrations ranging from $30-36 \mathrm{~g} \mathrm{~N} \mathrm{~kg}^{-1}$ for the $\mathrm{cv}$. 'Violet de Rennes' grown in Bologna, Italy, under irrigated and rain-fed conditions. According to our previous study (Liu et al., 2012), the clones planted in 2011 suffered a longer period of environmental water deficit than clones planted in 2008. The severe soil moisture deficit period, which is defined as a period of soil moisture potential greater than $50 \mathrm{kPa}$, lasted for 124 days and 147 days in 2008 and 2011, respectively. The N, P and K concentrations and accumulations in 2008 were therefore greater than those in 2011 and were accounted for by the reasons outlined above.

\section{Potential uses of the clones}

In comparisons with other main energy crops, $\mathrm{N}$ concentration level (3.98-9.50 $\mathrm{g} \mathrm{N} \mathrm{kg}^{-1}$ ) in the tuber of Jerusalem artichoke was lower than that in sweet sorghum $\left(9-10 \mathrm{~g} \mathrm{~N} \mathrm{~kg}^{-1}\right)$ reported by Han et al. (2011). The tuber also exhibited the similar $\mathrm{N}$ concentration level with miscanthus shoot (Beale and Long, 1997) and switch grass shoot (Wilson et al., 2013).

Jerusalem artichoke aboveground parts showed relatively higher $\mathrm{N}$ (7.87-22.66 $\mathrm{g} \mathrm{N} \mathrm{kg}^{-1}$ ) and $\mathrm{K}$ concentration levels (14.53$20.38 \mathrm{~g} \mathrm{~K} \mathrm{~kg}^{-1}$ ) in this study in comparison with some main forage crops. Sudangrass shoot N concentration was found to be $2.39 \mathrm{~g} \mathrm{~N}$ $\mathrm{kg}^{-1}$ ( $\mathrm{Li}$ and $\left.\mathrm{Lu}, 2006\right)$. Annual brome (Haferkamp and Heitschmidt, 1996) exhibited $\mathrm{K}$ concentration level ranging from 1.7 to $14.8 \mathrm{~g} \mathrm{~K} \mathrm{~kg}^{-1}$. However, $\mathrm{P}$ concentration in above ground parts, with the reverse, was lower in Jerusalem artichoke $(0.83$ $\left.1.65 \mathrm{~g} \mathrm{P} \mathrm{kg}^{-1}\right)$. It was reported in the range between $1.8-2.0 \mathrm{~g} \mathrm{P} \mathrm{kg}^{-1}$ for red clover (Davies et al., 1966) and between 2.4-2.6 $\mathrm{g} \mathrm{P} \mathrm{kg}^{-1}$ for white clover (Wang, 1982), and between 1.6-2.9 $\mathrm{g} \mathrm{P} \mathrm{kg}^{-1}$ for annual brome (Haferkamp and Heitschmidt, 1996). P concentration in alfalfa shoot $\left(4.7 \mathrm{~g} \mathrm{P} \mathrm{kg}^{-1}\right)$ was found to be even higher (Xiao and Zhao, 2006).

Cluster $\mathrm{K}_{4}$, which includes CQ-1, GZ-1 and HUN-3 clones, includes the most appropriate clones for energy production, as these clones contain a high $\mathrm{N}$ concentration in tubers (mean $8.42 \mathrm{~g}$ $\mathrm{N} \mathrm{kg}^{-1}$ ) and low $\mathrm{N}$ concentration in aboveground parts (mean $11.43 \mathrm{~g} \mathrm{~N} \mathrm{~kg}^{-1}$ ). The pellet and briquette industry requires a lower concentration of $\mathrm{N}$ in raw materials because the combustion of biomass pellets and briquette would directly release the $\mathrm{N}$ in the raw materials into the environment in the form of toxic pollutants (Jenkins et al., 1998). Therefore, aboveground parts derived from these clones would be appropriate for pellet and briquette production. While the high $\mathrm{N}$ content of tubers precludes their use for pellet and briquette production, anaerobic digestion of tubers for ethanol production would benefit from their high $\mathrm{N}$ concentration; higher $\mathrm{N}$ concentrations confer value to post-digestion residues to enhance their use as crop fertiliser (Demuynck, 1984; Hons et al.,
1993; Karpenstain-Machan, 2001). Therefore, these three clones could efficiently furnish ideal raw materials for both pellet/briquette and ethanol energy-production processes, with additional benefits. Clusters $\mathrm{K}_{6}$ and $\mathrm{K}_{2}$, including 16 clones in total, would be most suitable to be used as forage, as these clones contain higher mean $\mathrm{N}$ concentrations in aboveground parts. The mean aboveground $\mathrm{N}$ concentrations of $\mathrm{K}_{6}$ and $\mathrm{K}_{2}$ were 13.09 and $12.83 \mathrm{~g} \mathrm{~N}$ $\mathrm{kg}^{-1}$, respectively. If the total $\mathrm{N}$ had been converted into protein (total $\mathrm{N} \times 6.25$ ), the crude protein in aboveground parts would be calculated to range from $5.0 \%-14.3 \%$ and $2.5 \%-6.3 \%$ for $\mathrm{K}_{6}$ and $\mathrm{K}_{2}$ clusters, respectively. These crude protein content values are higher than those of maize and wheat used for dairy cow feed and thus could be useful as forage (Zhao et al., 2011). Furthermore, Rakhimov et al. (2003) found this plant to have a high nutritive value, as it contains almost all essential amino acids needed for livestock feed. Stauffer et al. (1981) also agreed that the aboveground part is better suited for use as feed than are tubers, as the leaf is rich in lysine and methionine.

In contrast to the $\mathrm{N}$ results above, however, our results demonstrate that the P content of Jerusalem artichoke shoots is insufficient for dairy feed $\left(0.81-1.65 \mathrm{~g} \mathrm{P} \mathrm{kg}^{-1}\right)$, in agreement with results reported by Kays and Nottingham (2008). Seiler and Campbell (2006), who have reported the influence of heritable variation on mineral content, recommend elevating the $\mathrm{N}, \mathrm{P}$ and $\mathrm{K}$ content using hybrid-breeding methods. However, the $\mathrm{P}$ and $\mathrm{Mg}$ content would hardly be elevated using this method, since the P content in this plant is already generally lower than in forage feed.

$\mathrm{K}$ is an element that is important for its roles in osmotic adjustment and enzyme catalysis. Sufficient supply of K is also important in dairy feed. The 26 clones were demonstrated to possess $\mathrm{K}$ concentrations ranging from 11.87 to $20.38 \mathrm{~g} \mathrm{~K} \mathrm{~kg}^{-1}$ and would thus provide nutritionally adequate amounts of $\mathrm{K}\left(5.1-19.0 \mathrm{~g} \mathrm{~K} \mathrm{~kg}^{-1}\right)$ to serve as a valuable ruminate feed supplement (National Academy of Sciences, 2001).

\section{Conclusions}

The N, P and $\mathrm{K}$ concentrations and biomass accumulations in 26 Jerusalem artichoke clones collected from 18 provinces in China showed significant variation, with levels that tend to be lower under drought conditions. If optimal cultivation conditions can be sustained, this crop is a promising source of raw materials for use in the biomass energy industry, as well as for forage feed from the perspective of macroelement concentration. Three clones, CQ-1, GZ-1 and HUN-3, are recommended for use as biomass energy materials and 16 clones are recommended for use as forage feed. The clones' phenotypic nutrition traits described in this work should aid quantitative trait locus (QTL) mapping of their germplasms for future development of improved varieties tailored to diverse applications and growth conditions.

\section{Highlights}

The aboveground parts exhibited higher $\mathrm{N}$ and $\mathrm{K}$ concentration levels and a lower of $\mathrm{P}$ concentration level than the tubers at maturity of Jerusalem artichoke.

Each of N, P, and K concentration was not significantly correlated with the plant biomass yield for the above ground parts and tubers respectively.

Jerusalem artichoke showed a relatively higher $\mathrm{N}$ and $\mathrm{K}$ uptake levels than sweet sorghum, miscanthus, and switchgrass, and $\mathrm{P}$ concentration with the reverse. 


\section{References}

Baldini M, Danuso F, Turi M, Vannozzi GP, 2004. Evaluation of new clones of Jerusalem artichoke (Helianthus tuberosus L.) for inulin and sugar yield from stalks and tubers. Ind. Crops Prod. 19:25-40.

Barloy J, 1988. Techniques of cultivation of the Jerusalem artichoke. pp 45-57 in Proceedings of first EEC Workshop on Jerusalem artichoke, Madrid, Spain.

Beale CV, Long SP, 1997. Seasonal dynamics of nutrient accumulation and partitioning in the perennial grasses Miscanthus $\times$ giganteusand Spartina cynosuroides. Biomass Bioenergy. 12:419-28.

Ben Chekroun M, Anizle J, Mokhtari A, El Haloui NE, Prevost J, Fontanillas R, 1996. Comparison of fructose production by 37 cultivars of Jerusalem artichoke (Helianthus tuberosus L.). New Zeal. J. Crop Hort. 24:115-20.

Buxton DR, 1996. Quality-related characteristics of forages as influenced by plant environment and agronomic factors. Anim. Feed Sci. Tech. 59:37-49.

Cheng Y, Zhou WG, Gao CF, 2009. Biodiesel production from Jerusalem artichoke (Helianthus Tuberosus L.) tuber by heterotrophic microalgae Chlorella protothecoides. J. Chem. Technol. Biotechnol. 84:777-81.

Conde JR, Tenorio JL, Rodríguez-maribona B, Ayerbet L, 1988. Tuber yield of Jerusalem artichoke (Helianthus Tuberosus L.) in relation to water stress. Biomass Bioenergy. 3:137-42.

Cosgrove DS, Oelke EA, Doll JD, Davis D, Undersander DJ, Oplinger ES, 2000. Alternate field crops manual: Jerusalem artichoke. Available from: http://www.hort.purdue.edu/newcrop/afcm/jerusart.htm

Crawford HS, Kucera CL, Ehrenreich JH, 1969. Ozark range and wildlife plants. USDA Agric. Handbook 356. U.S. Gov. Print. Office, Washington, DC, USA.

Davies EB, Watkinson JH, 1966. Uptake of native and applied selenium by pasture species: I. Uptake of Se by browntop, ryegrass, cocksfoot, and white clover from Atiamuri sand. New Zeal. J. Agr. Res. 9:317-27.

Demuynck M, 1984. Utilization in agriculture of anaerobically digested effluents. Commission of the European Communities: 62 .

Fernandez J, Curt MD, Martinez M, 1988. Productivity of several Jerusalem artichoke (Helianthus tuberosus L.) clones in Soria (Spain) for two consecutive years (1987 and 1988). Topinambour (Jerusalem Artichoke) Report Eur. 13405:61-6.

Haferkamp MR, Heitschmidt RK, 1996. Mineral dynamics of forages during the growing season. J. Range Manage. 49:234-40.

Han LP, Steinberger Y, Zhao YL, Xie GH, 2011. Accumulation and partitioning and nitrogen, phosphorus and potassium in different varieties of sweet sorghum. Field Crop Res. 120:230-40.

Hay RKM, Offer NW, 1992. Helianthus tuberosus as an alternative forage crop for cool maritime regions: a preliminary study of the yield and nutritional quality of shoot tissues from perennial stands. J. Sci. Food Agric. 60:213-21.

Hons FM, Cothren JT, Vincent JC, Erickson ML, 1993. Land application of sludge generated by the anaerobic fermentation of biomass to methane. Biomass Bioenergy. 5:289-300.

Honermeier B, Runge M, Thomann R, 1996. Influence of cultivar, nitrogen and irrigation on yield and quality of Jerusalem artichoke (Helianthus tuberosus L.). pp 35-36 in Inulin and Inulin Containing Crops - Proceeding of the Sixth Seminar on Inulin.

Huxley A, 1992. The RHS dictionary of gardening. Macmillan, London, UK.
Jackson ML, 1958. Soil chemical analysis. Prentice Hall Inc., Englewood Cliffs, NJ, USA.

Jenkins BM, Baxter LL, Miles Jr TR, Miles TR, 1998. Combustion properties of biomass. Fuel Process Technol. 54:17-46.

Karpenstain-Machan M, 2001. Sustainable cultivation concepts for domestic energy production from biomass. Crit. Rev. Plant. Sci. 20:1-14.

Kays SJ, Nottingham SF, 2008. Biology and chemistry of Jerusalem artichoke. CRC Press, Boca Raton, FL, USA.

Kosaric N, Cosentino GP, Wieczorek A, 1984. The Jerusalem artichoke as an agriculture crop. Biomass. 5:1-36.

Kowalczyk-Jusko A, Jozwiakowski K, Gizinska M, Zarajczyk J, 2012. Jerusalem artichoke (Helianthus Tuberosus L.) as renewable energy raw material. TEKA Commission of Motorization and Energetics in Agriculture, 12:117-21.

Lehtomaki A, 2005. Feedstocks for anaerobic digestion, in biogas from energy crops and agro wastes. Jyvaskyla Summer School, Jyvaskyla, Finland. Available from: http://www.cropgen. sotan.ac.uk/publication/AL\%20Feedstocks.pdf

Li XK, Lu JW, 2006. Effect of fertilization to the yield and N P K nutrient absorption of Sudagrass. Acta Agrestia Sinica. 14: 5256 [in Chinese with English abstract].

Lim KB, Lee HJ, 1983. Biomass production and cultivation of Jerusalem artichoke (Helianthus tuberosus L.) as an energy crop. Seoul Natl. Univ. Coll. Agric. Bull. 8:91-101.

Liu ZX, Han LP, Yosef S, Xie GH, 2011. Genetic variation and yield performance of Jerusalem artichoke germplasm collected in China. Agric. Sci. China. 10: 668-78.

Liu ZX, Spiertz JHJ, Sha J, Xue S, Xie GH, 2012. Growth and yield performance of Jerusalem artichoke clones in a semiarid region of China. Agron. J. 104:1538-46.

Ma XY, Zhang LH, Shao HB, Xu G, Zhang F, Ni FT, Brestic M, 2011. Jerusalem artichoke (Helianthus tuberosus), a medicinal salt-resistant plant has high adaptability and multiple-use values. J. Med. Plants Res. 5:1272-9.

Mezencev N, 1985. Premiers resultats des essais 1984 AZF/AFME sur topinambours betteraves en MidiPyrenees. AZF/CdF Chimie, Toulouse, 26 [in French].

Monti A, Amaducci MT, Venturi G, 2005. Growth response, leaf gas exchange and fructans accumulation of Jerusalem artichoke (Helianthus tuberosus L.) as affected by different water regimes. Eur. J. Agron. 23:136-45.

National Academy of Sciences, 2001. Nutritional requirements of dairy cattle. Available from: http://www.merckvetmanual. $\mathrm{com} / \mathrm{mvm} / \mathrm{management}$ and_nutrition.html

Nelson DW, Sommers LE, 1980. Total nitrogen analysis of soil and plant tissues. J. AOAC Int. 63:770-8.

Nemeth G, Izsaki Z, 2006. Macro- and micro-element content and uptake of Jerusalem artichoke (Helianthus tuberosus L.). Cereal Res. Commun. 34:597-600.

Niu JB, 2005. Jerusalem artichoke characteristics and high yield cultivation techniques. Gansu Agric. Sci. Technol. 7:40-1 [in Chinese].

Pilnik W, Vervelde GJ, 1976. Jerusalem artichoke (Helianthus tuberosus L.) as a source of fructose, a natural alternative sweetener. Zeitschr. Acker Pflanzenbau (Germany, FR) 2:142.

Rakhimov DA, Arifkhodzhaev AO, Mezhlumyan LG, Yuldashev OM, Rozikova UA, Aikhodzhaeva N, Vakil MM, 2003. Carbonhydrates and proteins from Helianthus tuberosus. Chem. Nat. Compd. 39:312-3.

Stauffer MD, Chubey BB, Dorrell DG, 1981. Growth yield and compositional characteristics of Jerusalem artichoke as they relate to biomass production. pp 79-97 in Fuels from Biomass 
and Wastes, Ann Arbor Science, Ann Arbor, MI, USA.

Seiler GJ, 1993. Forage and tuber yields and digestibility of selected wild and cultivated genotypes of Jerusalem artichoke. Agron. J. 85:29-33.

Seiler GJ, Campbell L, 2006. Genetic variability for mineral concentration in the forage of Jerusalem artichoke cultivars. Euphytica. 150:281-8.

Tilley JMA, Terry RA, 1963. A two- stage technique for the in vitro digestion of forage crops. Grass Forage Sci. 18:104-11.

Wang HX, 1982. The mineral content of forage feed effects on the livestock production capacity and health. Grassland and Turf. 4:1-8 [in Chinese].

Wilson DM, Heaton EA, Liebman M, Moore KJ, 2013. Intraseasonal changes in switchgrass nitrogen distribution compared with corn. Agron. J. 105:285-94.

Wolf B, 1982. A comprehensive system of leaf analysis and its use for diagnosing crop nutrient status. Commun. Soils Sci. Plant Analys. 13:1035-59.

Xiao M, Zhao RJ, 2006. Determination of mineral elements and industrialization prospect of alfalfa. Grain Oil Food Sci.
Technol. 14:48-9 [in Chinese].

Youngen JA, 1992. Jerusalem artichoke trials in Southern Oregon. Available from: http://ir.library.oregonstate.edu/xmlui/bitstream/handle/1957/5872/SR? sequence $=1$

Zhao FF, Zheng C, Li FD, Han XM, Hao ZL, 2011. Nutritional evaluation of Helianthus tuberosus meal on lactating dairy cows. Acta Pratacult. Sinica. 20:264-9.

Zhao GM, Mehta SK, Liu ZP, 2010a. Use of saline aquaculture wastewater to irrigate salt-tolerant Jerusalem artichoke and sunflower in semiarid coastal zones of China. Agric. Water Manage. 97:1987-93.

Zhao XF, Yang JS, Cai YM, Yao RJ, Li DS, Han JJ, 2010b. Effects of fertilization on the growth of Jerusalem artichoke and soil nitrogen accumulation in the coastal area of north Jiangsu province. J. Agro-Environ. Sci. 29: 521-6 [in Chinese with English abstract].

Zhu CX, Wu RN, Yu YQ, 2014. Effect of nitrogen on the plant height and dynamic allocation of Helianthus tuberosus. Acta Agrest. Sinica. 22:199-202. 